\title{
Ssciendo
}

Ethics \& Bioethics (in Central Europe), 2021, 11 (1-2), 92-100

DOI:10.2478/ebce-2021-0008

\section{The main principles and values of professional teaching ethics and their application in education}

\author{
Marta Gluchmanová1
}

\begin{abstract}
The author discusses professional teaching ethics and its main principles and values. The theoretical basis of the study is ethics of social consequences and, in its context, primarily the principles and values of humanity and human dignity, including their possible application in the teaching profession and, partially, in the process of teaching foreign languages and Slovak as a foreign language to students from abroad.
\end{abstract}

Keywords: ethics of social consequences, humanity, human dignity, professional teaching ethics, education

\section{Introduction}

As reasoning about professional teaching ethics primarily follows philosophical-ethical principles, the need also arises to reflect on ethical theories that could serve as the methodological basis in solving ethical and moral issues in the teaching profession. In ethics, there is no uniform or 'true' view of what is moral, immoral, correct or incorrect. This reflects how views of the world, our value system, and life experience differ, which, as a result, must, in some way, be reflected in our opinions on the criteria of the moral assessment of the behaviour and actions of an individual. This is also reflected in the plurality of ethical theories. It also fully applies to applied ethics, professional ethics, including professional teaching ethics (Kar, 2018, pp. 1729-1733).

Teaching ethics is understood as a branch of professional ethics, focused on the theoretical reflection of ethical and moral issues of the teaching profession (including defining the moral values, principles and norms of the teaching profession in the form of a code of ethics). Moreover, it also searches for answers, or solutions, to practical moral problems within the teaching profession. The base of teaching ethics is an interdisciplinary approach where philosophy, ethics, pedagogy, and psychology interact (Gluchmanová, 2013, p. 143). The whole area of professional teaching ethics is usually reduced to two main approaches, consequentialist and non-consequentialist (deontological), while such domains as ethics of virtue, discourse ethics, Kantian ethics, etc. are not really taken into account.

This is evidenced by, for instance, Kenneth A. Strike and Jonas F. Soltis who disregard the non-utilitarian version of consequentialism (within which Petit's virtual consequentialism, Slote's satisficing consequentialism, Jackson's probabilistic consequentialism, or Sena's evaluator relative theory fall) and reduce the whole of consequentialism to Jeremy Bentham's and John Stuart Mill's classic utilitarian version, i.e. the period from the end of the $18^{\text {th }}$ century until the second half of the $19^{\text {th }}$ century (Strike \& Soltis, 2004, pp. 12-14). In professional ethics in general, and especially in codes of ethics, a non-consequential, or downright deontological, approach is preferred (Brooks \& Dunn, 2009, p. 185; Crigger \& Godfrey, 2011, p. 7; Kuppermann, 2007, p. 135; Lucas, 2005, p. 41; Morrison, 2009, p. 27; Sethy, 2018, p. 297). In professional teaching ethics, consequentialist ethical theories are frequently depreciated as a potential instrument for, or source of, solutions to moral problems in the teaching profession while one-sidedly preferring deontological ethics, which requires the teacher to act on their moral duty while performing their profession (Campbell, 2008, p. 366).

\footnotetext{
${ }^{1}$ Technical University of Košice (Slovakia), e-mail: marta.gluchmanova@tuke.sk; ORCID: 0000-0003-36649218; Scopus ID: 36678819200
} 


\section{Ethics of social consequences as the theoretical basis of teaching ethics}

The present paper examines the possibility to apply ethics of social consequences as a version of non-utilitarian consequentialism in the form of a methodological basis of teaching ethics. The above ethical conception has been developed by Vasil Gluchman and his followers, while basing it on the principle and values of the consequences resulting from decisions and actions, or opinions and attitudes of a moral agent. The core of the value structure of this conception is formed by values of humanity, human dignity, and man's moral right. Among other values of this conception are justice, moral responsibility, responsibility, and tolerance (Gluchman, 2003, pp. 7-19; 2016, pp. 52-62; 2017, pp. 57-65; Kalajtzidis, 2018, pp. 2-13; Kalajtzidis, 2019, pp. 705-722; Polomská, 2018, pp. 137-183; Gluchmanová, 2013, pp. 141-160; Gluchmanová, 2018, pp. 262-280).

Ethics of social consequences has been the subject of constructive critical analysis and discussion for more than twenty years. There are a great number of positive statements expressing appreciation of its efforts to become a new approach, defining principles and values exceeding the traditional framework of consequentialist ethical theories, as well as producing stimuli that lead to the development of this ethical theory and polemics about some values and its emphasis on consequences. Undoubtedly, one of the most significant contributions to the discussion on ethics of social consequences is an analysis and assessment of this ethical conception by Teodor Münz, a renowned Slovak philosopher (Münz, 2002, pp. 275-284). Unlike other authors, who only focus on one of the aspects of ethics of social consequences, Münz carried out a complex analysis and assessment and defined ideas primarily concerned with the need to embrace biological sources of morality and moral values. Based on his analysis, he stated that "[...] Slovak, and perhaps also foreign, ethics has found in [Gluchman] an exceptional personality. He follows his own path, solves problems from his own viewpoint, he is thoughtful, conceptual, self-confident, brave, and his work is purposeful and systematic. That is, especially in Slovak philosophy, a common phenomenon" (Münz, 2002, p. 284). Similarly, before him, Jiří Kánský (a significant Czech ethicist working in Slovakia on a long-term basis) wrote about ethics of social consequences that it abandons the tradition of morality that is conventional in Slovakia and brings about new ideas and proposes a new ethical conception (Kánský, 1997, p. 487). ${ }^{2}$

The above principles and values of humanity, human dignity, and man's moral right are the main criteria for the assessment of a man's moral development in this conception. In keeping with the ethical theory, just actions respect and confirm the fundamental moral values valid in human society. The primary requirement for justice lies in that it must not deny any of the fundamental moral values. An action that is unjust can also be considered right, provided it brings about a prevalence of positive over negative social consequences. In this context, it should not be considered an unjust action; rather, the term non-just action is more appropriate, as it better fits the context and understanding of the criterion of moral assessment in this conception, i.e. consequences. Wrong and, mainly, immoral, actions must be labelled as unjust, especially due to the fact that, regardless their motives, they primarily bring about negative consequences. In such a case, intentional unjust actions must be differentiated from unintentional unjust actions; these are, however, still unjust (Gluchman, 2003, pp. 9-10).

The value of moral responsibility is, in ethics of social consequences, expressed by the principle of responsibility, which, together with other principles, such as the principle of humanity, justice, and tolerance, is an integral part of this conception. Within the ethical theory in question, moral responsibility is primarily concerned with respecting and pursuing man's

\footnotetext{
${ }^{2}$ The fundamental principles and values of ethics of social consequences are not only addressed by the Slovak, but also the international philosophical and ethical community (Dubiel-Zieliňska, 2018; Grzybek \& Domagala, 2018; Jemelka, 2018; Konstanczak, 2018; Kuře, 2018; Losyk, 2018; Misseri, 2018; Mysona Byrska, 2018).
} 
moral rights and dignity, i.e. the principle of humanity, which defines the main dimension of the principle of responsibility. In the author's opinion, responsible actions are just and in line with the principle of humanity. To practise common responsibility related to the pursuit of humanity, respecting human dignity, observing and pursuing human and moral rights, social institutions, which, indirectly, express not only mankind's common interests but also their shared moral responsibility, are necessary. Social institutions do not fully relieve an individual of their share of common responsibility. An individual's share in this responsibility varies and is defined by their social and political status, possibilities and abilities, which are, apart from other things, influenced by their education, upbringing and mental and physiological capabilities. What is, however, decisive is the individual moral responsibility of a moral agent when pursuing the principles of humanity and justice in specific everyday situations.

Here, immediate (direct) and mediated (indirect) responsibility must be considered. Immediate responsibility, for instance, occurs in the context of consequences directly resulting from the actions of a moral agent (set in motion by the agent's actions). The degree of mediated responsibility decreases in proportion with the time interval that has passed since the primary action of the moral agent. In this conception, moral duty is mainly defined at the theoretical level. It is a guide for a moral agent on how to contemplate, make decisions, behave, and act in specific everyday situations and how these principles should be applied in various circumstances. The principle of tolerance in the context of ethics of social consequences is limited by the principle of justice in actions as well as assessment. This means that, alongside the author of this conception, one could claim the following: The action is right if, and only if, it brings about a prevalence of positive over negative consequences and if it is in keeping with the principle of humanity". Moreover, the action is moral if, and only if, it produces almost exclusively positive consequences, if negative consequences are rare, and if the action is in keeping with the principles of humanity and justice (Gluchman, 2003, p. 16).

\section{The principle of humanity ${ }^{3}$}

In various contexts that are part of the school environment or the teaching profession as such, the actions of a moral agent usually bring about both positive as well as negative consequences. What is, however, important is that the moral agent who bases their thoughts, decisions and actions on these principles and values, chooses and pursues such actions that result in a prevalence of positive over negative consequences. The consequences that arise relate to the individual and the environment they live and work in and which they influence by their actions. Provided the actions and behaviour of moral agents (in this case, teachers) are aimed at protecting and supporting children and youths, i.e. the development, of human life, it could be claimed that the moral agent acts humanely. Humanity stands for all forms of behaviour and actions directed at the protection and support, i.e. development, of human life. In Gluchman's opinion, following the latest knowledge of natural sciences, ${ }^{4}$ the main form of humanity, lies in the protection and support, i.e. the development of one's own life and the lives of their close ones, friends, relatives and acquaintances. He calls in a natural-biological trait we share with many other animal species. This all results in the fundamental rights and obligations regarding

\footnotetext{
${ }^{3}$ In the context of ethics of social consequences, I work with its author's understanding of morality and moral values, which is, to a significant extent, also marked by the latest discoveries of natural science pointing to the natural-biological basis of human behaviour, including morality (in this context humanity as well as human dignity). The author of this conception has been, among others, also motivated by Münz and his analysis (Bekoff, 2004, pp. 489-520; 2006, pp. 71-104; McKenzie Alexander, 2007; Münz, 2002, p. 281; Prinz, 2007).

${ }^{4}$ Genetics, neurology, biology, zoology, ethology, etc. keep bringing about new knowledge regarding the similarities man shares with the rest of the animal kingdom, such as brain activity, behaviour and actions that are identical or similar to many members of the animal kingdom, such as primates and mammals (but not only these). Münz previously pointed to strong anthropocentrism of ethics of social consequences and the need for taking man's biological dimension into regard, as it significantly influences his morality (Münz, 2002, pp. 281-284).
} 
the protection and support of human life. The protection and support of human life usually brings out positive social consequences (Gluchman, 2013, p. 127) It seems that this opinion of his corresponds with present-day philosophy and ethics where the emphasis is shifted from exclusively anthropocentric understanding of morality to socio-biological or, possibly, biocentric, which also takes, to various extents, the influence of the biological determination of human behaviour and actions into account. It is something that might be disputed; human biological relatedness to the animal kingdom cannot, however, be denied, as, according to the findings of natural science, is, often, much deeper than one wishes to admit and accept in humanity-related areas of cognition.

When it comes to the application of ethics of social consequences in teaching practice, or the education process as a whole, it must be admitted that a teacher's reasoning, decision making and acting in accordance with its principles and values is more demanding than following other ethical theories. This theory requires more effort when pondering upon and assessing one's actions from several potential perspectives before one acts and considers the possible resulting consequences and decides based on that, while realising the associated responsibility. This ethical conception provides a teacher with more options and greater freedom when making decisions and acting; it, however, places greater responsibility upon them in comparison with such conceptions as, for instance, deontological ethics. According to this conception, a teacher's duty, primarily, lies in acting in line with approved, or generally accepted, rules and values established within the profession in question (most commonly expressed in the form of a code of teaching ethics), regardless their applicability in solving specific moral problems or the consequences that follow. This is not some kind of 'moral arithmetic', as one can never exactly calculate positive and negative social consequences but rather a model of morally rational reasoning based on strictly defined criteria which provide good conditions for a teacher to make free decisions and act when addressing moral issues and problems within their professional and educational work.

At present, when the education system is transforming, humanity is emphasised in the interaction with and among students, as well as among the teaching staff, and in the education process in general, i.e. the focus is placed on the personality of the educated as a human individuality with the right to their own decisions and development (Kafi, Motallebzadeh \& Ashraf, 2018, p. 4). Equality and humanity should be the norms for the relationships between educators and the educated. In a humanely-oriented school, the emphasis is placed on the cultivation of man, mutual relationships, as well as the general morale. If all moral agents (including students as potential moral agents) at school as well as out-of-school facilities behave and act according to such criteria, it should lead to the support and protection of the lives of students and youths and, at the same time, produce positive social consequences. Humanity is especially important when, for instance, teaching a foreign language and especially when working with foreign students, as these are often representatives of different cultures, religions, as well as social, political, or ethnic backgrounds who brought with them to the new university (quite often on a different continent) environment their own values, customs, and traditions.

In general, it could be said that school and its environment contributes to humanity and care for the protection of their students, which suggests that school primarily produces positive social consequences. However, at the same time, when new trends arise in the life of society, some individuals understand freedom and democracy in a different way, which also brings about new problems and challenges for the teaching profession and teaching ethics. There is information about increased aggression and violence among children and youths, as well as cases of teachers not behaving in accordance with the requirements of humanity when, for instance, they do not strive to protect human life and instead, oftentimes, expose themselves or others to various types of danger (fights, theft, bullying) in school or out of it. This can be even more precarious if foreign students are involved. 
Thanks to the application of ethics of social consequences, its principles and values in teaching ethics and especially in the teaching profession, positive thinking and adequate motivation, skills necessary for social life and progressive interpersonal relationships (also with foreign students) are shaped, while moral way of thinking, right decision making, predicting, and accepting responsibility for one's moral and educational decisions are taught. All this produces positive consequences in the teaching profession towards teachers but, mainly, on the part of teachers towards their students. It could then be stated that ethics of social consequences has a great potential to be applied in teaching ethics and the teaching profession as such.

On the other hand, Vasil Gluchman, in the context of the above-mentioned latest knowledge of natural science, claims that the protection and support of lives of strangers or unknown people is a moral surplus value, by which a new, higher, quality in one's behaviour and actions towards other people is created. It concerns humanity as a moral trait, or surplus value; it is something extra, which is truly specifically human and, in any case, worthy of respect and admiration. By such behaviour, man confirms he can, at least to a certain extent, exceed the natural-biological framework of its determination (Gluchman, 2013, p. 127). ${ }^{5}$

School is concerned with the protection and support, development, upbringing and education, and cultivation of students (unlike other professions where the clientele is more stable), i.e. actually strangers and unknown people (especially in the case of foreign students). In this way, a higher quality in behaviour and actions is shaped. That is why I believe that teachers' work for the benefit of others (students) is worthy of respect and admiration and truly a moral surplus value contained and pursued within the teaching profession. By emphasising humanity as a moral surplus value produced by one's actions for the benefit of strangers and unknown people, ethics of social consequences clearly defines a value framework, which is, to the full extent, acceptable for the teaching profession, as it is space inherent to this profession - help others, educate, cultivate their overall (including moral) development. In this way, ethics of social consequences in professional teaching ethics named the core of its efforts. The teaching profession, thus, becomes the creator of a moral surplus value on an individual, as well as social, level.

The existence of exceptions, i.e. cases that are in contradiction to the tendency of pursuing humanity in the teaching profession, merely confirms how demanding the teaching profession is, as teachers are, for the entire working time, exposed to significant mental and emotional load issuing from a great number of objective and subjective factors. If one of these factors fails to work, or plays a negative role to an extent that is greater than it should be, then the teacher might fail in the effort to solve a specific moral or educational problem. In the context of ethics of social consequences, even these situations should be concerned with assessing the teacher's actions in a broader context rather than based on a single act and the consequences resulting from it. Primarily, an effort should be made for a clear prevalence of positive over negative social consequences in each individual moral agent working as a teacher, and a clear effort to achieve and pursue humanity in the possible problems and drawbacks of one's actions. Nevertheless, in no way should clearly inhumane actions (be it on the part of the teacher or students) be tolerated, or even justified, that would endanger the lives of children and youths, or deny their human dignity.

\footnotetext{
5 The term 'moral surplus value' expresses a higher moral value of certain behaviour or action as opposed to common everyday behaviour and actions of an individual. A similar concept can also be found in Immanuel Kant (1724-1804) in the difference between hypothetical and categorical imperative, John Stuart Mill (1806-1873) in qualitatively deferring forms of pleasure, or George Edward Moore (1873-1958) in joining several forms of good when, in his view, an additional value, or additional good, is produced.
} 


\section{The principle of human dignity}

According to Vasil Gluchman, there are two aspects of human dignity in ethics of social consequences. The first one is related to the value of life that deserves respect and appreciation, which results in positive social consequences that are a function of human dignity. The other aspect concerns human dignity being the function of positive social consequences resulting from one's behaviour and actions that are to be prevalent over negative social consequences. Based on this, a qualitative or surplus value of human dignity can be ascribed to a moral agent (Gluchman, 2019, p. 1130).

When discussing professional teaching ethics, mutual respect and appreciation must be emphasised not only towards the students, as pointed out by some authors, but, at the same time, make sure it is also teachers who are respected and appreciated. Only then can one talk about successful mutual relationships not only between the teacher and the student, but also within the teaching staff, between teachers and their superiors, etc. Human dignity stands for respect of a human being regardless their age, i.e. dignity is also observed with regard to children in preschool facilities and so are students of primary and secondary schools and universities; regardless their sex, religion or religious belief, race and ethnicity, political views, as well as their national and social background. This applies to an even a greater extent at present, when a great number of foreign students study at Slovak universities. This follows from the first way of understanding human dignity within ethics of social consequences, since every human individual, based on their species affiliation, is worthy of respect and appreciation. This, first, aspect of understanding human dignity is especially significant for children and youths. Every individual, thus, has the right to the protection of and respect for their human dignity (and, consequently, freedom and security) at school as well as during out-of-school activities.

School education should be aimed at full-value development of one's personality and enhancing the respect for human rights. It is to aid mutual understanding, tolerance, and friendship. This aspect places emphasis on the realisation of one's duty to accept this value and express respect, mainly on the part of teachers towards their students. On the other hand, it also entails the duty, or obligation, within the teaching profession, for teachers to lead and educate children and youths towards mutual respect and appreciation of human dignity in other children as well as adults. Just as the students' cognitive and intellectual abilities increase, according to ethics of social consequences, so does their way of assessing their human dignity also change. Through gradual cognitive and intellectual development, children and youths change from purely passive bearers of human dignity (merely based on their species affiliation) and work their way through to a position where they, to a significant extent, build their respect and appreciation of themselves, based on their behaviour and actions. It is this process of realising one's human dignity and showing respect and appreciation to others that is a moral and educational task, or duty, of the teaching profession (naturally, it is not only a teacher's task and duty).

I have to state that fulfilling this moral and educational task is not always successful in the teaching profession, since there is a lack of qualified teachers at (especially primary and secondary) schools, while those qualified might also fail to manage specific situations that require an educational and moral intervention. Discipline and manifestations of violence in, as well as outside, school pose a problem. In this case, these are also problems related to human dignity and its degrading or breaking (Klembarová, 2015, pp. 31-38).

There is space to apply the principles and values of ethics of social consequences in solving these moral and educational issues within the teaching profession and teaching ethics in general. The key to approaching contemplations on human dignity in the teaching profession is differentiating between the developmental stages of human dignity, as defined by this conception. It is the difference between the basic level of understanding human dignity and the resulting respect and appreciation of a human being based on their species affiliation, associated 
to unconditional respect and appreciation that children of pre-school age, or students at the first level of primary school, are due. From (approximately) this period on, the second stage of shaping one's human dignity starts to shape (as a result of the development of cognitive, mental, emotional, intellectual, and moral qualities of children and youths), which manifests through, apart from their species affiliation, behaviour and actions, which gradually affects the respect and appreciation of these children and youths.

This process culminates in the third stage of the development of human dignity, when it is assumed the individual meets the criteria of a moral agent (secondary school students in the final year of their studies and university students) and human dignity reflects the consequences of their behaviour and actions. It, thus, follows that teachers should show full respect for children's human dignity while in the first stage, in the second, and especially the third, stage the respect and appreciation of human dignity of students is correlative, i.e. results from, among other things, their behaviour and actions towards teachers and other people taking part in the education process, as well as people outside this environment. This does not, however, mean that teachers should have the right to degrade the human dignity of those students who behave inappropriately towards other people in class or school (including teachers). Rather, it should serve to explain or justify that, in such cases, the teacher has the right, and even a moral duty or justification, to choose a different approach and relationship to such individuals, as opposed to those who are worthy of their full respect and appreciation.

What is, however, highly surprising is that a great number of school representatives claim there are no serious educational or moral problems (such as bullying) present at their school, or they downplay the obvious problem. It might be caused by the fact that not even adults are sometimes able to recognise negative action of students. Sometimes, teachers and other pedagogical employees also become participants in bullying. A decisive approach of educators when exposing bullying is of a paramount moral importance, as this reassures students such phenomena are, in the school environment, impermissible. Teachers, however, make several mistakes: they sometimes indirectly express their agreement with the practices of the initiators of bullying; they initiate the whole mechanism (by mocking an individual in front of the whole group); they downplay the extent and gravity of bullying at their school; they tend to ignore bullying, as they are unable, for multiple reasons, to discipline the bullies. Physical consequences might quickly disappear but emotional wounds are deep and their healing often complicated.

\section{Conclusion}

In conclusion, it could be stated that ethics of social consequences, by means of its principles and values, has the potential to contribute to the development of the theory of research into teaching ethics, as well as to the solving of moral issues related to the teaching profession. This ethical conception concerns, on the one hand, actions directed at the achievement of positive social consequences while respecting the values of humanity, human dignity, and moral rights; on the other hand, such actions that respect the above values and bring about positive social consequences, which is the core of the ethical theory in question. Ethics of social consequences, as well as in professional teaching ethics, is primarily concerned with positive social consequences which, however, must follow the principles and values of humanity, human dignity, and man's moral right and, possibly, other values, such as justice, responsibility, tolerance, commitment, etc.

Another argument in favour of ethics of social consequences is the fact that, according to this conception, when addressing moral issues, every moral agent should take regard for the justified needs and interests of other people, i.e. students, colleagues, parents, while also expecting these people to also take in consideration his justified needs and interests. In this way, one-sided overrating of students' welfare can be avoided (which, in some approaches, is often 
the case), as the teaching profession should not one-sidedly favour of the teachers' duties and the students' rights, but rather a complementarity of rights and duties (including the moral right) of all parties.

\section{Acknowledgment}

The paper is the result of the solution of the project KEGA 001TUKE-4/2019 Innovative methods and forms of education.

\section{References}

BEKOFF, M. (2004): Wild justice and fair play: Cooperation, forgiveness, and morality in animals. In: Biology and Philosophy, 19(4), pp. 489-520.

BEKOFF, M. (2006): Animal passions and beastly virtues: Cognitive ethology as the unifying science for understanding the subjective, emotional, empathic, and moral lives of animals. In: Zygon, 41(1), pp. 71-104.

BROOKS, L. J. \& DUNN, P. (2009): Business \& professional ethics for directors, executives $\&$ accountants. Mason, $\mathrm{OH}$ : Cengage Learning.

CAMPBELL, E. (2008): The ethics of teaching as a moral profession. In: Curriculum Inquiry, 38(4), pp. 357-385.

CRIGGER, N. \& GODFREY, N. (2011): The making of nurse professionals: A transformational, ethical approach. Sudbury, MA, London: Jones \& Barlett Learning.

GLUCHMAN, V. (2003): Human being and morality in ethics of social consequences. Lewiston, NY: Edwin Mellen Press.

GLUCHMAN, V. (2013): Humanity: biological and moral issues. In: V. Gluchman (ed.): Morality: Reasoning on different approaches. Amsterdam \& New York: Rodopi, pp. 111-130. GLUCHMAN, V. (2016): Disaster issues in non-utilitarian consequentialism (ethics of social consequences). In: Human Affairs 26(1), pp. 52-62.

GLUCHMAN, V. (2017): G. E. Moore and theory of moral/right action in ethics of social consequences. In: Ethics \& Bioethics (in Central Europe), 7(1-2), pp. 57-65.

GLUCHMAN, V. (2019): Human dignity as the essence of Nussbaum's ethics of human development. In: Philosophia 47(4), pp. 1127-1140.

GLUCHMANOVÁ, M. (2013): The teacher as a moral agent: Humanity and human dignity in the teaching profession. In: V. Gluchman (ed.): Morality: Reasoning on different approaches. Amsterdam \& New York: Rodopi, pp. 141-160.

GLUCHMANOVÁ, M. (2018): Moral right and justice in the teaching profession. In: V. Gluchman (ed.): Ethics of social consequences: Philosophical, applied and professional challenges. Newcastle upon Tyne: Cambridge Scholars Publishing, pp. 262-280.

GRZYBEK, G. \& DOMAGALA, J. (2018): Ethics of social consequences: Applied theory in forming social ethos. In: V. Gluchman (ed.): Ethics of social consequences: Philosophical, applied and professional challenges. Newcastle upon Tyne: Cambridge Scholars Publishing, pp. 253-261.

JEMELKA, P. (2018): Environmental ethics in the context of ethics of social consequences. In: V. Gluchman (ed.): Ethics of social consequences: Philosophical, applied and professional challenges. Newcastle upon Tyne: Cambridge Scholars Publishing, pp. 212-234.

KAFI, Z., MOTALLEBZADEH, K. \& ASHRAF, H. (2018): Developing, localizing validating code of professional ethics through PLS-SEM: EFL university instructors' perspectives In: Cogent Education, 5(1), pp. 1-22.

KALAJTZIDIS, J. (2019): Ethics of social consequences as a hybrid form of ethical theory? In: Philosophia, 47(3), pp. 705-722. 
KALAJTZIDIS, J. (2018): Responsibility and justice: secondary values in ethics of social consequences. In: V. Gluchman (ed.): Ethics of social consequences: Philosophical, applied and professional challenges. Newcastle upon Tyne: Cambridge Scholars Publishing, pp. 2-23. KAR, S. (2018): Professional ethics of teacher educators in relation to value pattern. In: Indian Journal of Public Health Research and Development, 9(12), pp. 1729-1733.

KÁNSKÝ, J. (1997): Podnětná původní práce z etiky [Inspiring original work on ethics]. In: Filozofia, 52(7), pp. 487-489.

KLEMBAROVÁ, J. (2015): The school classroom as a prejudice-free zone. In: Ethics \& Bioethics (in Central Europe), 5(1-2), pp. 31-38.

KONSTANCZAK, S. (2018): Ethics of social consequences and the Polish philosophical tradition. In: V. Gluchman (ed.): Ethics of social consequences: Philosophical, applied and professional challenges. Newcastle upon Tyne: Cambridge Scholars Publishing, pp. 58-71.

KUPPERMAN, J. (2007): Ethics and qualities of life. Oxford: Oxford University Press.

KUŘE, J. (2018): Ethics of social consequences within (bio)ethical concepts: A comparative study on the concept and methodology of ethics of social consequences and principlism. In: V. Gluchman (ed.): Ethics of social consequences: Philosophical, applied and professional challenges. Newcastle upon Tyne: Cambridge Scholars Publishing, pp. 88-118.

LOSYK, O. (2018): Postmodern relativism in the context of ethics of social consequences: Selected aspects of potential interaction. In: V. Gluchman (ed.): Ethics of social consequences: Philosophical, applied and professional challenges. Newcastle upon Tyne: Cambridge Scholars Publishing, pp. 24-48.

LUCAS, P. (2005): Humanising professional ethics. In: J. Strain \& S. Robinson (eds.): The teaching and practice of professional ethics. Leicester: Troubador, pp. 40-50.

MCKENZIE ALEXANDER, J. (2007): The structural evolution of morality. Cambridge: Cambridge University Press.

MISSERI, L. E. (2018): Ethics of social consequences and reputation capital in cyberspace. In: V. Gluchman (ed.): Ethics of social consequences: Philosophical, applied and professional challenges. Newcastle upon Tyne: Cambridge Scholars Publishing, pp. 298-319.

MORRISON, E. E. (2009): Health care ethics: Critical issues for the 21st century. Sudbury, MA \& London: Jones \& Barlett Learning.

MÜNZ, T. (2002): Etika sociálnych dôsledkov Vasila Gluchmana [Ethics of social consequences of Vasil Gluchman]. In: Filozofia, 57(4), pp. 275-284.

MYSONA BYRSKA, J. (2018): The ethics of world of consumption and the ethics of social consequences: A Few Remarks. In: V. Gluchman (ed.): Ethics of social consequences: Philosophical, applied and professional challenges. Newcastle upon Tyne: Cambridge Scholars Publishing, pp. 49-57.

POLOMSKÁ, J. (2018): Human dignity within ethics of social consequences. In: V. Gluchman (ed.): Ethics of social consequences: Philosophical, applied and professional challenges. Newcastle upon Tyne: Cambridge Scholars Publishing, pp. 137-183.

PRINZ, J. J. (2007): The emotional construction of morals. Oxford: Oxford University Press.

SETHY, S. S. (2018): Academic ethics: Teaching profession and teacher professionalism in higher education settings. In: Journal of Academic Ethics, 16(4), pp. 287-299.

STRIKE, K. A. \& SOLTIS, J. F. (2004): The ethics of teaching. New York: Teachers College Press. 